\title{
Water Consumption Patterns and Waterborne Diseases in Slums of Karachi
}

\author{
Shuja Ur Rehman \\ PhD Student, Department of social work, \\ University of Karachi, Pakistan \\ Saima Baig \\ Sindh Madressatul Islam University, Pakistan
}

Corespodance Author: PhD in Social Work, Assistant Professor,

\section{Doi:10.5901/ajis.2017.v6n1p37}

\section{Abstract}

The prime objective of the present study was to evaluate the water consumption patterns and systems in relation to water borne diseases in slum areas of Karachi. It also aimed to, to highlight the major incidence of water-borne diseases due to unhygienic practices and also investigated the role of Government and Non-Governmental Organizations for the provision of safe drinking water. The field-based exploratory approached and quantitative method of research was operated and has been given weighted in accordance with the primary data collection. A structured interview schedule was used as the tool for the collection of data. Descriptive and inferential statistical techniques were used for the purpose of interpretation of the results. The result of the study indicates and elaborates that the people in slum areas of Karachi face problems related to water shortage, water pollution and water borne diseases. The results also depict that the majority of the population suffered from water related diseases such as Typhoid, Dysentery, Diarrhea, etc. The result of the study clearly highlights the fact that the condition of water supply system is quite unhygienic and poor which is the main cause behind the outbreak of these diseases.

Keywords: Unsafe water, Water borne diseases, Slum areas, Consumption pattern, NGOs.

\section{Introduction}

Water is essential for life on the earth. Without water people and other creatures cannot survive for more than a few days. It is one of the valuable natural resources on earth and has no substitute. Every individual requires a minimum body intake of 2.5 liters' clean water on the daily bases. It depends upon the climatic conditions where he/she lives too. Water is normally taken into the body as one of the ingredients of food and drink. The intake must balance the body and loss from breathing, sweating and excretion. Every living thing i.e. plants, animals and human beings need water for the in survival. In fact, every living thing needs water, thus human body contains about two-third of water to survive (Trividi and Raj 1992).

Clean and fresh water is needed for human health and socio-economic development. The water permeates society and its availability impacts all human efforts, economical, ecological, or social. In the $21^{\text {st }}$ century, fresh and clean water resources are going scarce across the world. In many countries of the world, climate change and increasing water use has constrained the availability of fresh water (Fozia 2010). A few years ago, Pakistan was rich with fresh water resources, but unfortunately, at present it is facing severe water shortage. The atmospheric and climate changes, particularly an unnatural weather change pattern, shifting of monsoon and intensity of precipitation in the country are further aggravating the already served water accessibility situation. The rapid growth of population in the country would need extra fresh water resources to meet the domestic, agriculture and industrial requirements. The quality of the fresh water resources is also rapidly reducing in the country because of the entry of sewage and industrial effluent into the freshwater resources. In the agriculture sector, Pakistan is the main user of freshwater. It consumes about 90 percent of 
fresh water resources of the country. The other uses of water include domestic water use, industrial water use and water for nature (United Nations Industrial Development Organization 2003).

In Pakistan as everywhere, water remains an important resource to sustain well-being of citizens. Water shortage and increasing competition for multiple use of water has adversely affected the water quality. Therefore, water pollution has become a serious problem in Pakistan. In developing countries like Pakistan, over 60 percent diseases are the consequence of contaminated water (World Wildlife Fund Pakistan 2007).

More than 38.5 million people are deprived of safe drinking water and 50.7 million people have lack of access to improved sanitation in Pakistan (Qadeer 2009) Because of water borne diseases and illnesses an estimated number of 230,000 children deaths is recorded every year in Pakistan (Fozia 2010).

There are many diseases associated with water, such as Typhoid fever, Cholera, Diarrhea and Dysentery. These are liabilities on public health system and also can result in significant economic loss. The estimated cost of environmental degradation in Pakistan is 365 billion rupees per year, out of which 112 billion rupees is due to with inadequate water supply sanitation and hygiene (Ministry of Finance Pakistan 2014).

It is estimated that more than three million individuals suffer from water related pathogens in Pakistan such as Typhoid, Diarrhea, Dysentery and Hepatitis each year, of which one million die, (UNIDO 2003) including 200,000 children of less than five years' age (Demographia and Demographic 2016).

Karachi is a major urban and industrialized city of Pakistan. It is one of the twenty mega cities of the world, having a population of about 22 million people (Haq 2014) and covers an area of more than 800 square kilometers. The city is faces all kinds of environmental problems, including drinking water contamination and inadequate water supply. Residential areas in Karachi are divided into planned and unplanned areas. More than 40 percent of city's population resides in squatter settlements (Yousuf, Siddiqui and Khan, 2014). Unplanned areas are those where there is lack of proper shelter, water supply and other utilities essential for survival. In these areas, many people are living without access to safe drinking water and this is the most important determinant to be focused. Karachi receives water from the Indus River, Hub dam and Dumlottee reservoirs through the municipal water pipeline. However, supplies are inadequate to meet the increasing demand of water. The utilization of domestic water use in the city is 195 liters per person per day. Water quality is another problem, rapid growth of population and industrialization are the major reason behind water pollution in Karachi. Filtration plants are installed in different areas, but unfortunately, plants are limited in their capacity to filter water. Although, 60 percent water supply to the city is made through a filtration process, the remaining is disinfected through colonization. Neither of these methods is sufficient to purify water. The measures to prevent users from receiving contaminated water are also infected (Guriro 2009). Many areas in Karachi have been facing fresh water scarcity for a long time, particularly in slum localities. Water related diseases are certainly much higher in the slum localities of Karachi where contaminated water is held the cause. According to Yousuf et al. (2014) more than 30,000, people, 20,000 of whom are children, die annually in Karachi alone due to use of polluted water (Ministry of environment of environment 2009). There is no state-run water system in Karachi's rural areas like Ibrahim Haydari, Rehri Goth and Bhutta village. Most of the people of these areas have been consuming underground water, which contains fluoride and arsenic substances, which are very dangerous to human health. Because of the utilization of underground, salty water in different areas of Rehari Goth and Ibrahim Hyderi two hundred cases of children were reported who were suffering for paralysis and lower limbs in 2009 (Tahir, Rasheed and Imran 2010).

National drinking water policy was approved in 2009. The aim of the policy is to bring improvement in the existing system, initiate new water supply system and make available safe drinking water for entire population to reduce death and diseases toll caused by water borne-diseases (Hyder, Arsha and Aziz, 2009) because safe water can reduce diarrhea and other related diseases up to 50 percent. There is an urgent need to implement National drinking water policy in the country, to provide safe drinking water for the entire population and save the precious lives and reduce a huge amount of money which is being spent on water related diseases.

\subsection{Objectives}

The objectives of this study are as under:

- To find out the social determinants of water-borne diseases.

- To know level of diseases in the community due to unhygienic practices.

- To find out the role of Government and Non-Governmental organizations for preventing of water bornediseases. 


\section{Method and Material}

Study Design: Community based survey study design was conducted.

Study area and Period: The present study was exploratory in nature. The universe of the present study comprises the slums in various areas of Bin Qasim and Keamari town of Karachi.

The study was conducted from October 2014 to March 2015 in the slums of Karachi. The total population of these areas was 34,329 .

Population Sources: All households residing in the slums of Bin-Qasim and Kemari town of Karachi.

Sample Size Calculation: The calculated sample size was 379 respondents were selected for the present study as per population with the help of Kregcie \& Morgan 1970. Data was collected through a well-structured interview schedule.

Sampling Method: 379 respondents were selected using simple random sampling techniques.

Data Analysis: Data were interpreted and analyzed through Statistical Package for Social Sciences (SPSS) version 19; the data were presented in bivariate and univariate tables for descriptive and inferential statistics were also used for analysis.

\section{Results}

Table 1: Demographic Indicators

\begin{tabular}{lcc}
\hline \multicolumn{1}{c}{ Indicator } & Frequency & Percentage \\
\hline Age group & $\mathbf{N}$ & $100 \%$ \\
18-29 years & 128 & \\
30-41 years & 188 & $33.78 \%$ \\
42 years and above & 63 & $49.60 \%$ \\
\hline Education levels & & $16.62 \%$ \\
Illiterate & 238 & \\
Up to metric & 97 & $62.79 \%$ \\
Metric & 25 & $25.59 \%$ \\
Intermediate & 8 & $6.60 \%$ \\
Graduation & 5 & $2.11 \%$ \\
Masters & 2 & $1.32 \%$ \\
Vocational/diploma certificate & 4 & $0.53 \%$ \\
\hline Occupational status & & $1.06 \%$ \\
Fishermen & 302 & \\
Driver & 48 & $79.68 \%$ \\
Security guard & 11 & $12.66 \%$ \\
Other & 18 & $2.91 \%$ \\
\hline Household income (per month) & & $4.75 \%$ \\
Less than 10,000 & 33 & $8.71 \%$ \\
$10,000-15,000$ & 139 & $36.68 \%$ \\
16,000-20,000 & 93 & $24.54 \%$ \\
21,000 and above & 114 & $30.07 \%$ \\
\hline
\end{tabular}

See Table: 1. above the table presents the socio-economic dynamic situation, where respondents were involved to collect the data such as age, educational status, income and source of income in the slum areas of Karachi. 49.6 percent, respondent were from 30-41 years' age group, while 33.78 percent of the respondents were between the age of 18-29 years group, while remaining 16.62 percent were in the age group of 42 years and above.

The demographic factor depicted that more than half of the respondents were illiterate i.e. (62.79) percent and 25.59 percent of the respondents were educated up to the matric level are followed by matric 6.60 percent, while 2.11 percent respondent acquired education till intermediate level and 1.32 percent were graduates and 1.06 percent respondents had a vocational/diploma certificates, while remaining only 0.53 acquired education at postgraduate level. The level of education creates awareness about water contamination and its terrible impacts on human health and also water purification practices among the community. But unfortunately most of the population was illiterate in shanty towns, of Karachi.

The table further indicates that the distribution of respondents about their profession in which more than half of the 
respondents were fishermen i.e. (79.68) percent, whereas 12.66 percent respondents were drivers and 4.75 percent respondents belonged to other professions (not specified), whereas remaining 2.91 percent as security guards, data also disclosed that (36.68) percent of the respondents' monthly household income was between Rs.10000-15000, whereas 30.07 percent of the respondents' monthly household income was Rs.21000 and above, and 24.54 percent of the respondents' monthly household income was between Rs.16000-20000, while remaining 8.71 percent respondents had less than Rs.10,000 income. During survey, it was observed that most of the people of these areas live in miserable conditions. Standard of living is very low and poor become they cannot afford to buy clean water for drinking purpose. As already mentioned above that the people of slum areas of Karachi are not financially stable to manage and purchase mineral water for them.

Table No 2: Access and Knowledge of Contaminated Water

\begin{tabular}{lcc}
\hline \multicolumn{1}{c}{ Indicator } & Frequency & Percentage \\
\hline \multicolumn{1}{c}{$\mathbf{N}$} & 379 & $100 \%$ \\
Sources accessible & & \\
Bore well & 58 & $15.30 \%$ \\
Public tap & 135 & $35.62 \%$ \\
Piped water at home & 75 & $19.79 \%$ \\
Open well & 18 & $4.75 \%$ \\
Others & 93 & $24.54 \%$ \\
\hline Awareness about contaminated water & & \\
Yes & 370 & $97.6 \%$ \\
No & 09 & $2.3 \%$ \\
\hline Drinking water contamination awareness & & \\
Yes & 151 & $39.8 \%$ \\
No & 228 & $60.1 \%$ \\
\hline Source of knowledge & & \\
\hline \multicolumn{1}{c}{$\mathbf{N}$} & 151 & $100 \%$ \\
\hline By seeing & 59 & $39.07 \%$ \\
By drinking & 44 & $29.14 \%$ \\
By odor & 33 & $21.86 \%$ \\
By color & 10 & $6.62 \%$ \\
Through media & 04 & $2.65 \%$ \\
Other & 01 & $0.66 \%$ \\
\hline
\end{tabular}

See Table: 2. reveals that major sources available were public tape i.e., (35.62) percent, while 24.54 percent of the respondents obtained water from other sources (not specified). Access to pipe water at home was limited, i.e. 19.79 percent and 15.30 percent of the respondents obtained their water from bore well or hand pumps, whereas remaining 4.75 percent of the respondents had access to open well. Almost (97.62) percent of the respondents had awareness regarding contaminated water. They said that contaminated water was the leading cause of water related diseases while remaining 2.37 percent respondent perception was positive about contaminated water. They said it is not harmful for human health.

Further data shows that the majority of the respondents (39.84) percent was aware about the condition of their drinking water. They said their drinking water is contaminated and not fit for the health, whereas 31.93 percent respondents believe that their drinking water is safe to drink and remaining only 28.23 percent had no awareness about their water quality.

Respondents under study are 379 in number. 151 respondents were aware about their drinking water contamination. Therefore, respondents are 151. The above table shows majority of the respondents said that they came across by seeing water they used to drink is contaminated, i.e., (39.07) percent, while 29.14 percent came across by drinking. Data further depicts that 21.86 percent said that they came across by odor, whereas 6.62 percent of the respondents said that they came to know by color of water, followed by 2.65 percent of the respondents knew through the media, while remaining 0.66 percent of the respondents said that they knew through other sources (not specified). 


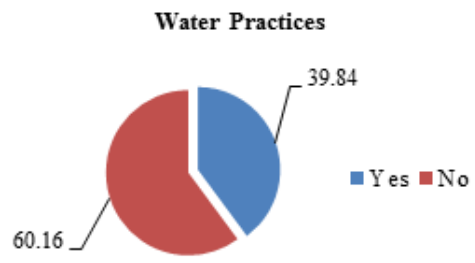

Figure 1: Above figure indicates that more than half of the respondents do not purify their drinking water, which is (60.16) percent, whereas remaining 39.84 percent of the respondents purify their drinking water.

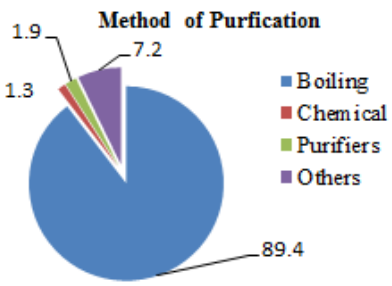

Figure 2: Above figure presents, that majority of the respondents (89.40) percent had used boiling method for treatment of water, while 7.28 percent said that they use other methods for water treatment (not specified) and 1.99 percent said that they use purifiers and remaining 1.33 percent use chemical method for treatment of water.

\section{Last Tow years Disease}

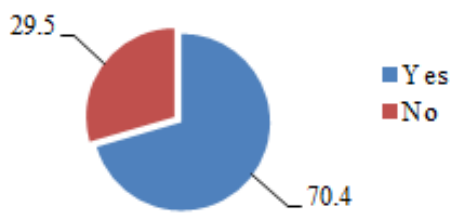

Figure 3: The figure shows that the majority of the respondents (70.45) percent stated that this had happened among less than five years' children in their family, while 29.55 percent responded negatively.

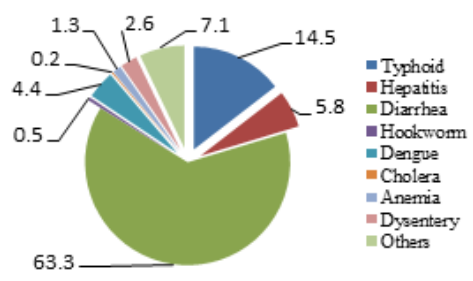

The above figure indicates that the highest number of the respondents (63.31) percent suffered from Diarrheal diseases, followed in number by Typhoid 14.50 percent. Table further depicts that 7.12 percent of the respondents were suffering of other diseases (not specified), while 5.81 percent suffered from Hepatitis and 4.49 percent respondents suffered of Dengue fever. The table also presents that 2.64 percent respondents suffered from Dysentery while 1.32 percent suffered from Anemia and 0.53 percent respondents suffering of a hookworm infection whereas remaining only 0.26 were suffering from Cholera. 


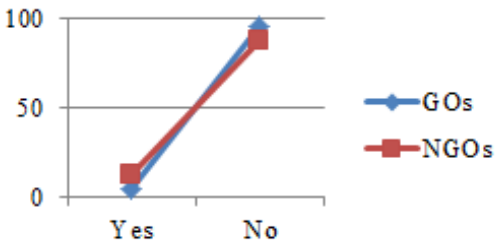

Figure 5: Shows a vast majority of the respondents said that Government/ Non-Government Organizations are not working against water pollution and dirt provision of safe drinking water in their locality, i.e. (95.1) percent. Whereas 12.40 percent said that Government/Non-Government Organizations are working for the prevention of polluted water in their area.

Evidence based statistical test proved strong relationship of the clean water supply and water borne diseases. So, we can overcome this issue through Governmental practices.

\section{Discussion}

Safe and healthy drinking water is the right of every individual. Contaminated drinking water increases the risk of numerous water related diseases such as Typhoid fever, Diarrhea, Dysentery, etc. in Pakistan, $13.6 \%$ of total deaths are caused due to water, sanitation and hygiene (Tahir, Rasheed and Imran 2010).

Drinking water quality in Karachi is very poor and indicates a potential source of human exposure to pathogenic bacteria species that can be contaminated by broken pipelines that affects water quality (Demographia and Demographic, 2016).

Mehboob ul Haq et al. (2014) conducted a survey on the title of "Drinking water contamination by chromium and lead in industrial leads of Karachi" in 2009, according to the survey report chromium and lead levels are highly responsible for water sources contamination in Karachi.

The present study clearly shows that the people in slum localities of Karachi have been facing water shortage, water pollution and water-diseases problems for a long time. Education creates awareness among people to use water purification techniques before they consume, but unfortunately it was found that most of the people of slum localities were illiterate; few of them have got education up to matric level. Only poverty was a common problem; the living condition of the people of these areas was very poor and lower standard. Due to financial problems, most of the people could not afford to buy clean water for drinking from the market. Fresh water from public tape was infrequent, and water supply from private vendors was very expensive. In the Bhutta village (Kamari town) people had been fetching water from the water tank, located 1 kilometer far from their houses for domestic consumption every day. They spend Rs.20/- to buy one plastic can of water; the majority of the people who are living their life on low social status earned only Rs.10, 000/- to 15, $000 /$ per month. So it was quite difficult for them to buy plastic bottles of fresh water. It was found that most of the people suffered from water related diseases such as Typhoid, Dysentery, Diarrhea, etc. The result of the study has clearly highlighted the fact that the condition of water supply system was unhygienic and poor.

\section{Conclusion}

Rapid population growth and economic activities are responsible for highly water consumption and drinking water pollution in slum localities of Karachi. In addition, lack of proper water management practices and improved sanitation has a direct impact on the quality of drinking water.

Finally, it is concluded that Government and Non-Governmental Organizations must focus on the alarming situation of these affected areas and make sure that each and every citizen of Pakistan has access to clean water to save precious human lives.

\section{Acknowledgements}

My gratitude to all those persons who supported me in this study. I am also thankful to community and community based 
organizations, which made adequate arrangements for data gathering and Government. officers for providing me security and road maps to approach the catchment area.

\section{Author Contributions}

Shuja ur Rehman performed the experiments on field site throughout study, contributed the material/analysis and making report and Dr. Saima Raheem Baig analyzed the data, defined methodology, wrote and reviewed the paper.

\section{Conflicts of Interest}

No any conflict of interst.

\section{References}

Demographia \& Demographic. (2016). world urban areas $12^{\text {th }}$ annual edition. Manila: p. 19.

Fozia, A. (2010). Water policy awaits Govt's approval. The Nation, Karachi., March 23. p. 3.

Guriro, A. (2009). Ibrahim Hydari and Rehri Goth provided relief, but receiving 3000,000 gallons. Daily Times, Karachi: Pakistan. December 13.

Haq, U.M. (2014). The rise of Karachi as a mega-city: Issues and challenges. Human development centre. Retrieved from http://www.mhhdc.org.

Hyder, S., Arsha, M \& Aziz, J.A. (2009). Evaluation of drinking water quality in urban areas of Pakistan: A case study of southern Lahore. Pakistan journal of engineering and applied science. VOL. 5, 16-23.

Ministry of environment of environment. (2009). National drinking water policy. Islamabad: 1-13.

Ministry of finance. (2014). Pakistan economy survey 2013-14. Federal budget publication.. pp. 145.

Qadeer, A. (2009). Impact of water and sanitation on health. $13^{\text {th }}$ National health sciences research symposium, Aga Khan University. Karachi:. pp. 27-28.

Tahir, A.M., Rasheed, H \& Imran, S. (2010). Water quality status in rural areas of Pakistan. Islamabad: Pakistan council of research in water resources. Ministry of science and technology. p.3.

Trividi, P.R., \& Raj, G. (1992). Encyclopedia of Environmental science: environmental air pollution. New Delhi: Akash deep publishing house.VOL.14, PP. 22-23.

United Nations Industrial Development Organization. (2003). Drinking water quality in Pakistan, in: The United Nations System in Pakistan: water a vital source of life. Islamabad:. p. 63.

World Wildlife Fund Pakistan. (2007). Pakistan water at risk: water \& health related issues in Pakistan and key recommendations. Lahore:. p. 10.

Yousuf, A.F., Siddiqui, R \& Khan, A.N. (2014). Survey of gram negative and gram positive bacteria in drinking water supplies in Karachi, Pakistan. British Microbiology journal. 4(6): 592-597. 